\title{
Két dísznövénykárosító molylepkefaj (Lepidoptera: Crambidae, Tortricidae) újabb szabadtéri előfordulása
}

\author{
TÓTH BALÁZS \\ Magyar Természettudományi Múzeum, Állattár, 1088 Budapest, Baross utca 13. \\ E-mail: toth.balazs@nhmus.hu
}

Kivonat. 2019. augusztus-szeptember fordulóján Budapest XXI. kerületében Csepelen lámpázással a Duponchelia fovealis ZELLER, 1847 (Crambidae) két hím egyedét észleltem, majd két újabb hím példány érkezett 2020 szeptemberében. 2020 júniusában Budapest belvárosában a Cacoecimorpha pronubana (HüBNER, 1799) (Tortricidae) imágóinak tömegrajzását figyeltem meg. Később, augusztusban, ugyanott ismét észleltem a C. pronubana néhány egyedét. Úgy tünik, az utóbbi faj a reggeli órákban repül, későbbi időpontban már nem látható. A C. pronubana fajnak ez a második publikált szabadföldi előfordulása Magyarországon. Most elöször történt imágók megfigyelése, mégpedig nagyobb egyedszámban. A $D$. fovealis esetében ez az első olyan kültéri megfigyelés, amikor két, egymást követő évben is észlelték. Mindkét faj potenciálisan veszélyes dísznövénykártevő, ám szabadtéri áttelelésük még nem bizonyított. A fajok bizonyító példányait a Magyar Természettudományi Múzeumban helyeztem el.

Kulcsszavak: Berberis, Cacoecimorpha pronubana, Duponchelia fovealis, idegenhonos faj, kártétel, új adatok

2019. augusztus 31-én éjszaka Budapesten, Csepelen egy családi ház kertjében személyes lámpázás során a fényre egy különös kinézetü tüzmoly érkezett. Ugyanazon a helyszínen, szeptember 5-én éjszaka PUSKÁS GELLÉRT kollégámmal gyüjtöttünk, és aznap ugyanennek a fajnak újabb egyede tünt fel (1. ábra). A lepkék azonosítása később történt: a Duponchelia fovealis ZELLER, 1847 (Crambidae: Spilomelinae) fajhoz tartoznak.

2020. június 12-én Budapesten, a Kálvin téren az M4 metró felvonójának kijárata köré ültetett cserjéken 7:50 h-kor sárgásbarna molylepkék rajzottak (2. ábra). Egyedszámuk igen magas volt, becslésem szerint elérte a százat. Lepkehálóval visszatértem a helyszínre (4. ábra) 8 h-ra. Ekkorra a repülés már alábbhagyott, nagyjából 30 példányt lehetett még megfigyelni. A lepkéket előzetesen a Cacoecimorpha pronubana (HÜBNER, 1799) fajnak véltem.

A lámpázások $160 \mathrm{~W}$ teljesítményű HMLI típusú izzóval történtek, hálózati áramról, $180 \times 240 \mathrm{~cm}$ méretű fehér színü lepedőt megvilágítva. A felszerelés egy melléképület lapos tetején, a járdaszinttől 2 m-rel magasabban kapott helyet. A lámpa sötétedéstől pirkada- 
tig világított. A lepkéket kloroformos ölöüvegbe gyüjtöttem. 2020. szeptember 21-én és 26-án egy-egy további $D$. fovealis hím példány jött a lepedőre.

A 2020. júniusi reggelen a lepkehálóval öt másodpercen át intenzíven csapkodtam a bokrok körül ott, ahol a legtöbb egyedet láttam, így 11 lepkét sikerült elfogni. A lepkehálót úgy hajtogattam össze, hogy ne tudjanak kirepülni belöle. Közvetlenül az elfogásuk után megtekintettem az aluljárónak a fentebb említett lelöhelytől kb. 15 m-re északkeletre (a Ráday utca túloldalán) lévő kijáratát. A Baross utca elejénél lévő kijáratok környékét nem vizsgáltam, viszont aznap munkahelyemről hazafelé menet 14:10 h-kor meglátogattam ezeket és a reggeli helyszíneket is.

A lepkehálót, benne a molyokkal, egy órára a Lepkegyüjtemény fagyasztóládájába helyeztem. Augusztus 7-én még egy egyed került elő 7:45 h-kor, a fentiekkel megegyező módon. A két faj összesen 16 példányát a Magyar Természettudományi Múzeum Lepkegyüjteményében helyeztem el. A lepkékről Olympus Camedia C 7070 fényképezőgéppel, az élőhelyekről Samsung S1070 fényképezőgéppel készültek felvételek.

A 2019-ben, ill. 2020 szeptemberében gyüjtött lepkékhez hasonlót a Magyar Természettudományi Múzeum Kárpát-medencei gyüjteményében nem találtam, viszont a palearktikus gyüjtemény segítségével sikerült azonosítanom: ezek a Crambidae családot képviselö Duponchelia fovealis ZELLER, 1847 = pontusi tüzmoly hím példányai. A palearktikus gyüjteményben 61 példányát örizzük, melyek Spanyolországból, Máltáról, Horvátországból, Szardíniáról, Albániából, Görögországból, Marokkóból, Tunéziából, Egyiptomból, Izraelböl és Törökországból származnak. KARSHOLT \& RAZOWSKI (1996) müve alapján a Mediterráneum országaiban, valamint Hollandiában honos; Dániába, Finnországba és Németországba behurcolták. A Csepelen augusztusban gyüjtött imágó igen kopott, a 2020. szeptember 21-én elfogott példány kopott, míg a többi két lepke ép.

A Tortricidae családot képviselő Cacoecimorpha pronubana begyüjtött példányainak mindegyike hím. Kettő szinte teljesen ép, frissen kelhetett, két példány pedig nagyon kopott, mintázatuk alig látszik; a szárnyak alapszíne kifakult. Az előzetes határozást FAZEKAS (2011) munkája és a múzeum palearktikus gyüjteménye alapján erösítettem meg. Ebben a gyüjteményben 49 példány található, melyek Spanyolországból, Máltáról, Horvátországból, Görögországból és Tunéziából származnak. KARSHOLT \& RAZOWSKI (1996) szerint Európában Hollandia, Svájc és Olaszország vonalában és attól nyugatra, valamint Romániában, Albániában és Görögországban fordul elő; Dániába behurcolták.

A növényeket, melyek körül a lepkék rajzottak, BARINA ZOLTÁN (Magyar Természettudományi Múzeum) a Berberis candidula SCHNEID. faj egyedeinek azonosította.

2020 júniusában a Ráday utca túloldalán lévő kijáratnál csak 5-10 példány repült, míg aznap délután már egyetlen C. pronubana imágót sem figyeltem meg.

Mivel FAZEKAS (2011) szerint e faj felbukkanása esetén kötelező ellene a védekezés, elektronikus levélben bejelentettem a megfigyelést a FÖKERT Zrt. központi ügyfélszolgálati címén. A bejelentést 2704/2020. számon iktatták, és válaszukban arról tájékoztattak, hogy a helyszíni ellenőrzés során az ő szakértőjük is észlelte a fajt; a szükséges permetezést elvégzik, amint az időjárás ezt lehetővé teszi, ezután pedig monitorozni fogják a területet. 

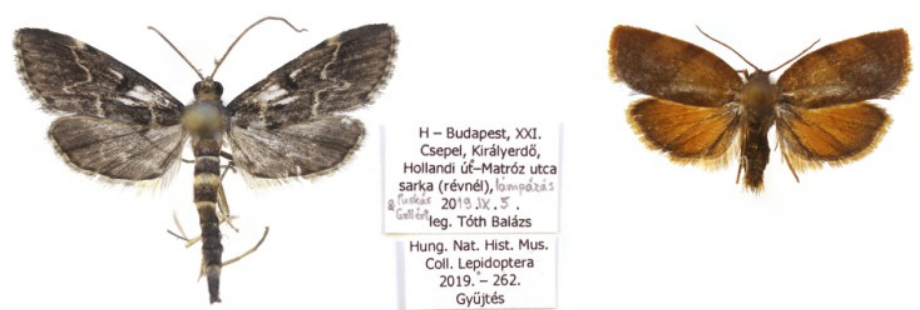

$\mathrm{H}$ - Budapest VIII.
Kálvin tér, M4 lift
Kán kjjárata (témplomn leg. Tóth Balázs Hung. Nat. Hist. Mus. Coll. Lepidoptera (2020. -295 Gyütés
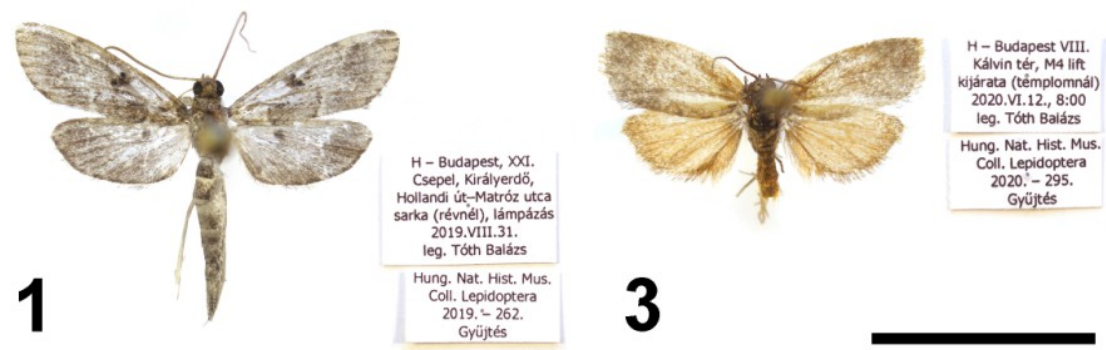

ation
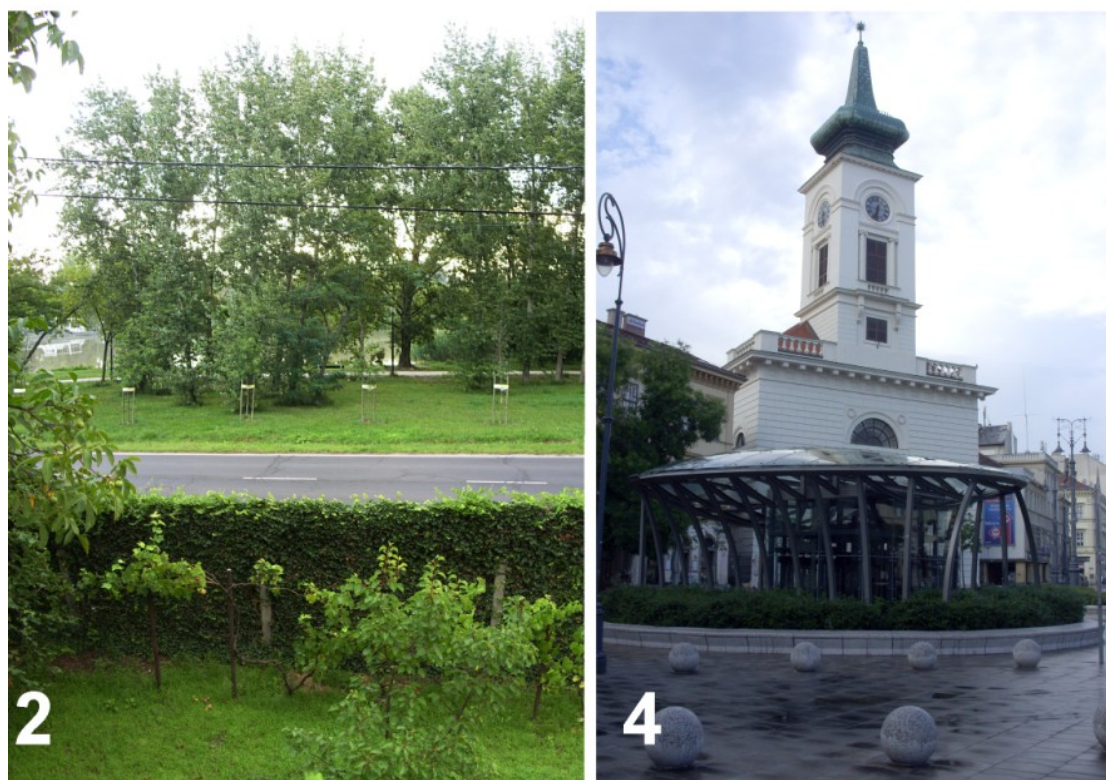

1-4. ábrák. Imágók és gyüjtőhelyeik. 1: A Duponchelia fovealis ZELLER, 1847 Csepelen 2019-ben gyüjtött példányai és céduláik; 2: Kilátás a csepeli gyüjtőhelyről kelet felé; 3: A Cacoecimorpha pronubana (HüBNER, 1799) Kálvin téren gyüjtött két példánya és céduláik; 4: A lelöhely; az M4 metró felvonójának kijárata köré ültetett borbolya (Berberis candidula) bokrok. Az 1. és 3. ábrák méretarányosak, lépték: $10 \mathrm{~mm}$.

Figures 1-4. Adults and their collecting sites. 1: Duponchelia fovealis ZELLER, 1847 specimens collected in Csepel, in 2019 and their labels; 2: view towards east from the Csepel locality; 3: two Cacoecimorpha pronubana (HÜBNER, 1799) specimens collected on Kálvin square and their labels; 4: the locality i.e. Berberis candidula bushes planted around the elevator exit of underground M4. Figures 1 and 3 are to scale, scale bar: $10 \mathrm{~mm}$. 
2020. augusztus 6-án 7:50 h-kor a C. pronubana öt egyedét figyeltem meg a felvonó kijáratánál, ám ezeket nem tudtam elfogni. Másnap, augusztus 7-én csak egyetlen egyedet találtam, melyet megfogtam.

A D. fovealis első hazai adatát SzABÓKY (1994) közölte: Szombathelyröl kapta két példányát. A 2000-es évek közepe óta egyre több kertészetben okoz károkat. Mindezidáig nagyon kevés szabadtéri adatát ismertük: egy példányt a sukorói növényvédelmi fénycsapda fogott 2010. június 7-én (SZEÖKE, pers. comm.); a budapesti Sas-hegyen működő fénycsapda gyüjtött egy imágót (HUNYADI 2014); végül a várpalotai Fajdas-hegyen, 2019. augusztus 21-én 1 hím és 1 nőstény repült fényre (leg. SzEÖKE KÁlMÁN; SzEÖKE, pers. comm). Az itt közölt csepeli előfordulások lelőhelye Budapest XXI. kerületének kertvárosi részén található, 50 m-re a Ráckevei-(Soroksári-) Dunától (3. ábra). Érdekességként megemlítem, hogy itt találták hazánkban először a Pechipogo plumigeralis (Hübner, 1825) fajt is (Lepidoptera: Erebidae, Herminiinae; TóTH et al. 2010).

A C. pronubana első hazai megfigyelését SzEŐKE (2002) jelentette Alsótekeresről (Enying), majd BODOR \& SzABÓKY (2010) Buda környékéről egy kertészetből. FAZEKAS (2011) a Corvinus Egyetem Villányi úti (Budapest XI. kerület) campusán talált egyedéröl ír. Hazánkban az első szabadföldi (vagyis épületek zárt terén, ill. kertészeteken kívüli) adatát FAZEKAS (2019) szolgáltatta, aki Szombathelyröl kapott egy kertben, borostyánon talált hernyóból nevelt imágót. Az eddigi hazai előfordulások közös jellemzője, hogy egyedi észlelések voltak: hernyót találtak, igen alacsony egyedszámban (egytől néhányig; BoDOR \& SZABÓKY (2010) nem adtak meg pontos értéket). A mostani megfigyelés viszont kizárólag imágók észlelését jelzi, ráadásul ugyanazon a helyszínen többször, egy esetben az eddigieknél jóval magasabb, a száz egyedet is elérő mennyiségben. Magyarországi imágók viselkedéséröl a jelen munka számol be először: úgy tünik, a lepkék reggel rajzanak, a nap további részében már nem láthatók - a rajzás kezdetének időpontja azonban továbbra sem ismert.

Feltünő volt, hogy - a látszólag - egymáshoz nagyon hasonló ültetett növénycsoportok közül csak az egyiket részesítették előnyben; talán ott voltak jelen nőstények. Elképzelhető, hogy a C. pronubana fajnak a Berberis candidula is tápnövénye, ám mivel se peterakást, se hernyókat, sem pedig kártételt nem figyeltem meg a növényen, a feltételezés megerősítésre szorul.

A fajt Magyarországon eddig csak a Dunától nyugatra figyelték meg, jelen adatok az elsők, melyek a Duna-Tisza közéről származnak, így a faj legkeletibb ismert előfordulását jelentik hazánkban.

Mindkét lepkefaj a Mediterráneumban őshonos, polifág: a C. pronubana lárváját eddig mintegy 170 növényfajról jelezték (FAZEKAS 2011), továbbá STOCKS \& HODGES (2011) 70 taxont sorolnak fel a $D$. fovealis tápnövényeként. Ezek széles köre miatt e rovarok potenciális veszélyt jelentenek egyes hazai kertészeti és mezőgazdasági növények számára. Kérdéses viszont, hogy Magyarországon szabadföldi áttelelésre, azaz tartós megtelepedésre képesek-e, követik-e olyan, dél felöl szétterjedt fajok példáját, mint a Cameraria ohridella DESHKA \& DIMIĆ, 1986 (Gracillariidae), a Libythea celtis (LAICHARTING, 1782) (Nymphalidae) vagy a Pechipogo plumigeralis. 
Köszönetnyilvánítás. Köszönettel tartozom BÁLINT ZsOLTnak és KATONA GERGELYnek (Magyar Természettudományi Múzeum), akik a kéziratot elolvasták és építő javaslataikkal segítették elkészültét. BusCHMANN FERENCnek (Jászberény) és SzeÖKE KÁLMÁNnak (Székesfehérvár) kritikai észrevételeiket és gyüjtési adatikat köszönöm. BARINA ZolTÁN (Magyar Természettudományi Múzeum) a Kálvin térre ültetett díszcserjék azonosításával nyújtott segítséget.

\section{Irodalomjegyzék}

Bodor J. \& SzABÓKy Cs. 2010. Szegfü-sodrómolyveszély. Kertészet és Szölészet 59 (45): 20-21.

FAZEKAS I. 2011. A Cacoecimorpha pronubana (Hübner, [1796-99]) új tápnövénye az Aeonium arboreum (L.) Webb \& Berthel. (Lepidoptera: Tortricidae). e-Acta Naturalia Pannonica 2 (2): $135-140$.

FAZEKAS I. 2019. A Cacoecimorpha pronubana (Hübner, [1796-99]) új tápnövénye Magyarországon a Hedera helix L. Microlepidoptera.hu 15: 29-34.

HUNYADI I. 2014. Új növényházi kártevő: a pontuszi tűzmoly (Duponchelia fovealis, Zeller 1847) Magyarországon. https://agraragazat.hu/hir/uj-novenyhazi-kartevo-a-pontuszi-tuzmolyduponchelia-fovealis-zeller-1847-magyarorszagon/(megtekintés 2020. augusztus 6.)

KARSHOLT O. \& RAZOWSKI J. (ed.) 1996. The Lepidoptera of Europe: a distributional checklist. Apollo Books, Stenstrup, $380 \mathrm{pp}$.

Stocks S. D. \& Hodges A. A. 2011. European pepper moth or Southern European marsh pyralid Duponchelia fovealis (Zeller). UF/IFAS Extension, EENY-508: 1-10. http://edis.ifas.ufl.edu/pdffiles/IN/IN91000.pdf (megtekintés 2020. október 2.)

SZABÓKY Cs. 1994. Molylepkefaunisztikai újdonságok: a hazai Anchia [sic] fajok elterjedése és a Duponchelia fovealis Zeller, 1847 elsö hazai adata. New data for the Hungarian Microlepidoptera fauna: the Hungarian distribution of Anchia [sic] species and the first Hungarian record of Duponchelia fovealis Zeller, 1847. Folia entomologica hungarica 55: 406-408.

SZEÖKE K. 2002. A szegfü-sodrómoly (Cacoecimorpha pronubana Hübner) megjelenése Magyarországon. Növényvédelem 38 (7): 353-354.

Tóth B., Petrányi G., SzabóKy Cs. \& Ronkay L. 2010. Polypogon plumigeralis (Hübner, [1825]) new for the Hungarian fauna (Lepidoptera, Noctuidae: Herminiinae). Folia entomologica hungarica 71: 157-160. 


\title{
Most recent outdoor records of two micromoth species (Lepidoptera: Crambidae, Tortricidae), pests of ornamental plants
}

\section{BALÁZs TÓTH}

Department of Zoology, Hungarian Natural History Museum, 1088 Budapest, Baross utca 13. E-mail: toth.balazs@nhmus.hu

ÁLLATTANI KÖZLEMÉNYEK (2021) 106(1-2): 000-000.

\begin{abstract}
Two male specimens of Duponchelia fovealis ZELLER, 1847 (Lepidoptera; Crambidae) were collected at lamplight at the turn of August-September 2019 in a suburban area of Budapest (21st district, Csepel). Later, in September 2020, two further male specimens were taken there. In June 2020, a mass outbreak of Cacoecimorpha pronubana (HÜBNER, 1799) (Tortricidae) was observed in the downtown of Budapest (Kálvin square), with males flying around the ornamental Berberis candidula SCHNEID. bushes, not later than 8:00 a.m. In August, a couple of males were still present in the locality. This is the second outdoor observation for C. pronubana in Hungary. Moreover, it is the first finding of any adult, plus the first observation of abundant presence of this species. For $D$. fovealis, these are the first data of outdoor occurrences in two subsequent years at the same locality. Both species are potentially harmful pests of ornamental plants but overwintering outdoors in Hungary is still not verified. Voucher specimens of both species are deposited in the Hungarian Natural History Museum.
\end{abstract}

Keywords: alien species, Berberis, Cacoecimorpha pronubana, damage, Duponchelia fovealis, new data 